\title{
Phonology of Children Aged 3 Years and 2 Months: Psycholinguistic Study
}

\author{
Ita Putriani ${ }^{1 *}$, Syahrul Ramadhan ${ }^{1}$, Agustina $^{1}$ \\ ${ }^{I}$ The Masters Program in the Language and Arts Faculty, Universitas Negeri Padang, Indonesia \\ "Corresponding author.Email: ita.putriani@gmail.com
}

\begin{abstract}
Every child gets a different language. Development of children's language production according to age. Children aged 3;2;0 in general have not been able to produce language perfectly. The purpose of this study is to describe the acquisition of phonology of children aged 3;2;0 years. This research is focused on the acquisition of phonology of children aged 3;2;0 years. This research method is descriptive with a qualitative approach. Researchers only listen to the utterances of research subjects without being involved in them. The technique used is record and note. After being selected and verified, audio data is recorded and transcribed together with their meanings. The results showed that children aged 3;2;0 mastered sounds, namely (1) vowel /a/, /e/, / $/ \mathrm{e} /, / \mathrm{i} /, / \mathrm{o} /, / \mathrm{o} /, / \mathrm{u} /, / \mathrm{\partial} / ;$ (2) diphthong /ao/ and /oi/; (3) bilabial /p/ and /b/ letup; alveolar letup /t/ and /d/; letup dorso velar /k/ and /g/; letup glotal /?/; palatal alloys /c/ and /j/; pharyngeal alloy /h/; alveolar shear /s/; nasal bilabial /m/; nasal alveolar /n/; nasal laminopalatal /ñ/; nasal dorsovelar /y/; lateral alveolar /1/; almost bilabial /w/; and almost palatal /y/.
\end{abstract}

Keywords: Language, phonology, and psychology

\section{INTRODUCTION}

Phonological acquisition is used as an effort to understand the sound of the language being heard. The child tries to sort out the words of his parents based on an assessment of the simplest grammar of the language conveyed by his mother. Phonological acquisition relates to the psycholingustic domain. Psycholinguistics is the study of psychology and linguistics whose object is the language used by humans (Kusuma, 2016; Miasari et al., 2015; Nuraeni \& Pd, 2015; Tussolekha, 2015; Yanti, 2016). Language acquisition as a psycholinguistic domain is developing rapidly. Acquisition of language in psycholinguistics is a process that takes place in a child's brain when he gets his first language (Dardjowidjojo, 2005). Language learning related to processes occurs when a child learns a second language after he has obtained his first language (Abdul Chaer, 2007).

Children grow and develop to obtain different languages. In general, these differences occur based on several factors such as the environment, physical, speech, ability to respond to information, and age. These factors can affect children in producing language sounds. In fact, in communicating children who have different ages affect the phonemes they say and cause delays in talking to children. Factors that can cause children to speak late are developmental maturity; ear factor; lack of intelligence; pronunciation support factors such as muscles around the mouth, oral cavity, and breathing; psychological factors; parenting factors; and information processing factors (Maria van Tiel, 2015).

Several studies conducted with child phonology have been conducted. These studies found problems with children's language sounds. The child is not fluent in syllables or words. Many words spoken are not the same as the actual words. The ability of every child (Anggaira, 2016; Apriani, 2019; Budhiono, 2011; Haryanti, Lestari, \& Sobari, 2018; Purba, 2018; Putri, Rasna, \& Suandi, 2014; Saputri, 2018; Ulfa, 2017).

Children's language abilities at age $3 ; 2 ; 0$ are not perfect. Children often experience errors in pronouncing language when talking, so that there are certain phonemes that are obscured and changed. The misrepresentation of these phonemes will be examined in the acquisition of phonology. The importance of assessment of the child's phonology is carried out because the acquisition of the child's phonology influences the linguistic sciences that discuss the complexity, regularity, and limitations of the sound system. This research was conducted as an effort to assist parents in supervising children's language, anticipating language errors that are being taught that can change meaning, as well as helping identify disturbances that occur in children's utterances.

The problems related to the acquisition of children's phonology have indeed been carried out by many previous 
researchers, but research on children aged $3 ; 2 ; 0$ no researchers have conducted research. Therefore, research on the acquisition of phonology of a child named Arsyla Vera Gazala. In the research process, several problems related to phonemes and phoneme change have been found. Misappropriation and change in phonemes can be caused by the surrounding environment that utters words that are not in accordance with the actual phonemes. Habits like these can affect the child's acceptance of the language being spoken. The reason is that the acquisition of children's language is imperfect and affects phonemes that have an impact on the meaning of language that is not the same. Therefore, research on the acquisition of phonology of children aged $3 ; 2 ; 0$ psycholinguistic studies.

\section{METHOD}

This study uses a description method with a qualitative approach. This research is to describe language acquisition in phonology. The subject of this research is Arsyla Vera Gazala who was born on February 25, 2016 and is now $3 ; 2 ; 0$. The method of collecting data is a method of listening and engaging. Researchers in listening to the utterance of the subject are not involved in it. The technique for recording data is the record and note technique (Sudaryanto, 2016). After being selected and verified, audio data is recorded and transcribed together with their meanings. For the purposes of discussion in the field of phonology, data is distributed into smaller parts of phonemes and syllables.

\section{RESULTS AND DISCUSSION}

The study of phonology has two forms, phonetic and phonemic. Phonetics is the sound of language without regard to meaning, while phonemic is the sound of language that pays attention to meaning (Abdul Chaer, 2007). Phonological analysis on Arsyla Vera Gazala focused on the phonetic form. The reason, this analysis was carried out to describe Arsyla Vera Gazala's more centralized and more detailed utterances. Data from the child's utterance is written to see the ability to produce sound from an utterance. The data obtained by researchers are data in the form of utterances of children aged $3 ; 2 ; 0$.

At the age of 3;2;0, Arsyla interacts in the environment like adults. He is able to understand and carry out commands and is able to produce language until those around him understand some of the meaning of his words. When Arsyla was ordered to imitate her mother's words, she understood the meaning of her mother imitating them. In addition, when Arsyla was ordered to recite prayers that she had learned, she was able to recite them. However, not all sounds produced are pronounced correctly. There are a number of sounds in words that are spoken incorrectly when they are combined in words.

(1) Tak tlepon-tlepon. Tak tlepon telos. Ngantok. Pləp pləp pləp. Apəl. əndas. Konco.

The data above shows that at age $3 ; 2 ; 0$, Arsyla's ability to produce vowels is at high vowels $/ \mathrm{i} /$ and $/ \mathrm{u} /$ middle vowels /e/, /o/, and /o/; and low vowel /a/. Then viewed from the shape of the mouth, at the age of 3;2.0 Arsyla was able to produce round vowel sounds $/ \mathrm{o} /$ and $/ \mathrm{u} /$ and nonround vowel /i/ and /e/.

Having observed and connected with the context at that time, the [pləp] utterance is not known by the author. In fact, utterances delivered by Arsyla have been understood. At the age of 3,2,0 arsyla is able to pronounce the sound /i/ in the word [clay] which means 'look' and the sound /u/ in the word [two] when Arsyla is invited to count. The sound $/ \mathrm{e} /$ and $/ \mathrm{o} /$ in the word [tlepon] which means 'telephone' because at that time Arsyla tried to communicate by calling. The sound $/ \mathrm{s} /$ in the word [konco] in Javanese which means 'friend'. The sound /a/ in the word [əndas] in Javanese means 'head'. Distribution and inventory of age 3,2, 0 vowel phonemes as follows.

Table 1. Distribution of Vocal Phonemes Ages 3, 2; 0 Years

\begin{tabular}{|c|c|c|c|}
\hline \multirow{2}{*}{ Phoneme } & \multicolumn{3}{|c|}{ Position in Word } \\
\hline & Early & Middle & End \\
\hline$/ \mathrm{a} /$ & $\sqrt{ }$ & $\sqrt{ }$ & $\sqrt{ }$ \\
\hline /e/ & $\sqrt{ }$ & $\sqrt{ }$ & $\sqrt{ }$ \\
\hline$/ \varepsilon /$ & $\sqrt{ }$ & - & - \\
\hline /i/ & $\sqrt{ }$ & $\sqrt{ }$ & $\sqrt{ }$ \\
\hline$/ \mathrm{o} /$ & $\sqrt{ }$ & $\sqrt{ }$ & $\sqrt{ }$ \\
\hline$/ \mathrm{a} /$ & $\sqrt{ }$ & $\sqrt{ }$ & $\sqrt{ }$ \\
\hline$/ \mathrm{u} /$ & $\sqrt{ }$ & $\sqrt{ }$ & $\sqrt{ }$ \\
\hline$/ \mathrm{a} /$ & $\sqrt{ }$ & $\sqrt{ }$ & $\sqrt{ }$ \\
\hline
\end{tabular}

Chart 1. Age 3, 2, 0 Year Vocal Inventory Early Middle End

High

I

E

Middle

$\mathrm{u}$

Under

a

The data above shows Arsyla ability to produce nonduplicate vocals. The following describes the dual vowels that are able to be spoken by Arsyla. Called double vowels or diphthongs because when producing sound, the position of the tongue at the beginning and end are not the same. The inequality is related to the height and low of the moving tongue and its structure. Diphthong sounds include /ai/ and /oi/. Here are some diphthongs produced at age 3;2;0 by Arsyla. The diphthong /ai/ sound of the word [hi] when greeting, /oi/ when calling remotely and /ai/. The data is not found in the data that states that Arsyla is able to produce diphthongs /au/. However, in the sound of diphthongs /au/, Arsyla has difficulty producing diphthongs /au/ in the word [hija] which should be pronounced with the sound [green]. The inventory of vocal phonemes of age $3 ; 2 ; 0$ is as follows. 
Bagan 2. Inventarisasi Diftong Usia 3;2;0 Tahun

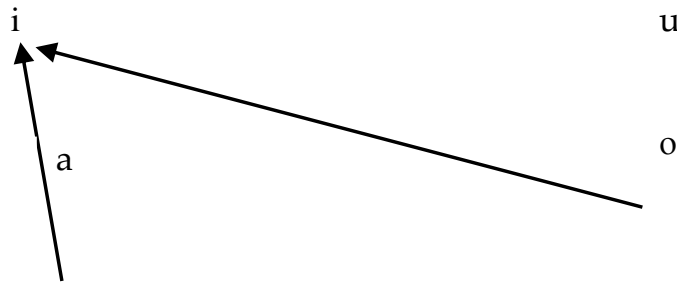

At the age of 3;2;0 Arsyla is able to produce several consonant sounds by means of fatigue. Bilabial consonant letup sounds / $/ \mathrm{p} /$ and $/ \mathrm{b} /$ are produced when Arsyla says the consonant letup sound $/ \mathrm{p} /$ on the word [four] and the consonant letup sound /b/ on the word [bato?] In Javanese which means 'forehead'. Alveolar letup /t/ consonant sounds in the word [tlepon] which means 'telephone' and alveolar letup /d/ in the word [əndas] in Javanese which means 'head'. The sound of the dorsovelar consonant letup $/ \mathrm{k} /$ in the word [diankat] and the dorsovelar consonant letup /g/ in the word [three]. Guide consonant sounds are sounds produced in a fricative way, ie active articulators fully block the flow of air, then form a narrow gap with passive articulators. In the consonant sound by means of the guide, Arsyla pronounces the palatal consonant sound /c/ in the word [washing] and palatal pannduan / $\mathrm{j} /$ in the word [guava]. The sound of consonants by sliding is found in the sound of alveolar consonants sliding / $\mathrm{s} /$ in the sound of [Asila] when introducing the name referred to is 'Arsyla'.

In addition to these sounds, some sounds produced at age $3 ; 2 ; 0$ are the sounds of nasal bilabial consonants,

Table 2. Consonant Inventory Age 3, 2, 0 Years

\begin{tabular}{|c|c|c|c|c|c|c|c|}
\hline & Bilabial & Alveolar & Lamono Palatal & Palatal & Dorsovelar & Pharyngel & Glotal \\
\hline Blast & $\mathrm{pb}$ & $\mathrm{td}$ & & & $\mathrm{kg}$ & & $?$ \\
\hline Alloys & & & & $\mathrm{c} \mathrm{j}$ & & $\mathrm{h}$ & \\
\hline Shift & & $\mathrm{s}$ & & & & & \\
\hline Nasal & $\mathrm{m}$ & $\mathrm{n}$ & $\tilde{\mathrm{n}}$ & & y & & \\
\hline Lateral & & 1 & & & & & \\
\hline Hadap & $\mathrm{W}$ & & & $\mathrm{y}$ & & & \\
\hline
\end{tabular}

In fact, children aged $3 ; 2 ; 0$ are skilled at producing sounds and words, even sentences. The composition of words produced has also become increasingly complex. Words like eating, mother, father, and so on can be produced well. Here are a few words that Arsyla had produced at the age of $3 ; 2 ; 0$.

[hidun] 'nose' [ñamuk] 'mosquito'

[kupin] 'ear' [nañi] 'sing'

[for] 'teeth' [apəl] 'apple'

[bato?] 'brow' [hair] 'hair'

[kəpala] 'head' [konco] 'friend'

Data from the words above can be seen in the phonological ability data table for ages $3 ; 2 ; 0$. The data is as follows. bilabial endants, alveolar nasals, dorsovelar nasals, and palatal endings. In the sound of bilabial consonants by nasal means, Arsyla is able to produce sounds $/ \mathrm{m} /$ in words [mouth]. The sound of alveolar nasal $/ \mathrm{n} /$ Arsyla is produced in the word [untu] in Javanese which means 'teeth'.

The nasal laminopalatal consonant sound $/ \tilde{n} /$ in the word [ñokot] in Javanese which means 'bite'. In the nasal laminopalatal consonant, Arsyla still has difficulty in producing laminopalatal sound $/ \tilde{\mathrm{n}} /$ if there are two nasal laminopalatal consonant sounds / $\tilde{\mathrm{n}} /$ in one word, for example in the word [ñañi] which is pronounced with the word [nañi] in Javanese which means' berññi '. Nasal dorsovelar sound $/ \mathrm{y} /$ in the word [kenin]. The sound of a near palatal consonant $/ y /$ in the word [tayo] which is one of the children's films. The sound of a nearly bilabial consonant / w / in the word [wedok] in Javanese which means 'woman'. Next is the lateral alveolar sound $/ 1 /$ in the word [Gazala] when he introduces the name for its extension. 
family, and people who are considered as friends. At the phonological level, children aged $3 ; 2 ; 0$, still have difficulty pronouncing certain sounds. In receiving the sound, the child will try to make the sound he gets is the same or similar to the original sound. Efforts made by children aged $3,2,0$, are not always in line with expectations.

Children in their pronunciation are still having difficulty pronouncing some consonants that are not in accordance with their placement position. For example, the double vowel /au/ in the word [tiger] is always pronounced separately, namely [tiger] and morpheme /r/ in the word "hair" pronounced "peat." This difficulty occurs because there are two nasalization, the nasal and nasal nyi. For this reason, adults in speaking when they are together with small children must use good language so that the child imitates the good language.

\section{REFERENCES}

[1] Abdul Chaer. (2007). Linguistik Umum. Jakarta: Rineka Cipta.

[2] Anggaira, A. S. (2016). Pemerolehan Fonologi dan Metatesis: Studi Kasus Pada Anak Usia 2 Tahun 10 Bulan. Jurnal Pendidikan Bahasa Dan Sastra, 16(2), 213.

[3] Apriani, T. (2019). Pemerolehan Fonologi dan Leksikon pada Anaj Usia 3,6 Tahun: Kajian Psikolinguistik. Widyabastra, 07(1), 1-9.

[4] Budhiono, R. H. (2011). Pemerolehan Fonologis Pada Anak Usia 0-2 Tahun. Adabiyyāt: Jurnal Bahasa Dan Sastra, 10(1), 162.

[5] Dardjowidjojo, S. (2005). Psikolinguistik Kajian Teoretik. (Vol. 69, pp. 283-291). Vol. 69, pp. 283-291.

[6] Haryanti, E., Lestari, A. D., \& Sobari, T. (2018). Pemerolehan Bahasa Anak Usia 2-3 Tahun Ditinjau Dari Aspek Fonologi. Parole (Jurnal Pendidikan Bahasa Dan Sastra Indonesia), (1)(4), 591-602.

[7] Kusuma, A. B. (2016). Pemerolehan Bahasa Pertama sebagai Dasar Pembelajaran Bahasa Kedua (Kajian Psikolinguistik). Komunikasi Dan Pendidikan Islam, 5(2), 118-141.

[8] Maria van Tiel, J. (2015). Anakku Terlambat Bicara. Jakarta: Prenadamedia Group.

[9] Miasari, N., Widjajanti, A., Andianto, M. R., Studi, P., Bahasa, P., \& Unej, U. J. (2015). Pemerolehan Bahasa Indonesia Anak Usia Balita ( 4 - 5 Tahun ): Analisis Fonem dan Silabel Analysis of Phonemes and Syllable ). (2), 39-43.

[10] Nuraeni, L., \& Pd, M. (2015). Pemerolehan Morfologi (Verba) pada Anak Usia 3, 4 dan 5 Tahun (Suatu Kajian Neuro Psikolinguistik). 1(1), 13-30.

[11] Purba, H. S. R. (2018). Pemerolehan Fonologi Anak Usia 6 Tahun dengan Riwayat Kejang Demam. Linguistik: Jurnal Bahasa Dan Sastra,
3(1), 1-11.

[12] Putri, K., Rasna, I. W., \& Suandi, I. N. (2014). Pemerolehan Bahasa Indonesia Pada Anak Usia Dini Kabupaten Tabanan. Jurnal Pendidikan Dan Pembelajaran Bahasa Indonesia, 3(2), 1-10.

[13] Saputri, R. (2018). Pemerolehan Bahasa Anak Usia 3 Tahun. Jurnalistrendi, 2(4), 2010-2014.

[14] Sudaryanto. (2016). Metode dan Aneka Teknik Analisis Bahasa. In Universitas Sanata Dharma. Yogyakarta.

[15] Tussolekha, R. (2015). Mekanisme Pemerolehan Bahasa. Pesona, 1(2), 59-70.

[16]Ulfa, M. (2017). Pemerolehan Fonologi , Morfologi, dan Sitntaksis Anak Usia 2,5-3 Tahun. Prosiding Seminar Nasional Hasil Penelitian Pendidikan Pembelajaran STKIP PGRI Jombang, Jawa Timur, Indonesia, 3(1), 1-13.

[17] Yanti, P. G. (2016). Pemerolehan Bahasa Anak: Kajian Aspek Fonologi pada Anak Usia 2-2,5 Tahun. Jurnal Ilmiah VISI PPTK PAUDNI, 11(2), 131-141. 